\title{
Sex differences in the canalization of child growth and development: An example of genetic regulation
}

\author{
Horacio Lejarraga, M.D. ${ }^{a}$
}

\begin{abstract}
In case of a disease or nutritional deficit, the growth curve may show deviations from the percentile it was depicting, and once damage is removed, a strong regulatory force tends to restore its path. Such phenomenon is known as catch-up growth and is an example of canalization of growth. Girls are more favored than boys because, when faced with the same damage, their growth (and also their psychomotor development) shows less deviation than that of boys. Such difference is also shown in a higher prevalence among boys of growth retardation in general and some developmental disorders, including autism spectrum disorder and cerebral palsy. Infant mortality is lower in girls at all ages and life expectancy is several years longer in women from all countries. The cause of such differences in favor of girls has a strong genetic component and is enriching for the interpretation of clinical and epidemiological studies.

Key words: canalization, growth and development, sex differences, epidemiology.

http: / / dx.doi.org/10.5546/ aap.2021.eng.e473
\end{abstract}

To cite: Lejarraga H. Sex differences in the canalization of child growth and development: An example of genetic regulation. Arch Argent Pediatr 2021;119(5):e473-e479.

\section{CANALIZATION OF GROWTH}

Girls are better canalized than boys.

This simple phrase contains a very

a. Honorary Professor of Universidad de Buenos Aires, Autonomous City of Buenos Aires, Argentina.

E-mail address:

Horacio Lejarraga, M.D.: cursotesis07@gmail.com

Funding:

None.

Conflict of interest: None.

Received: 2-11-2021 Accepted: 4-20-2021 known across biological sciences in general, is less known in pediatrics. However, it is a biological concept that helps to make an adequate interpretation of child health clinical and epidemiological phenomena. For this reason, it is interesting to make a brief description about an example of genetic regulation.

When the growth curve for height of a boy or girl is plotted on a chart, it is observed that approximately between 2 and 10 years old, their growth goes parallel to and along percentile channels. Such trend to remain within the same channel is called canalization. ${ }^{1}$ Figure 1 shows the growth curve of a girl with normal development, parallel to and along the $25^{\text {th }}$ percentile, approximately, between 2 and 5 years, when the girl developed hypothyroidism due to lingual thyroid, which deviates her curve below the normal limits. Once diagnosed and managed adequately, the girl's growth rate speeds up above normal values, until her height reaches the percentile it had before the disease developed.

Such recovery, known as catch-up growth, ${ }^{1}$ is an example of canalization, which demonstrates the presence of a force maintaining the child's growth curve within a growth channel and, if it deviates for any reason, once the damage is removed, such force restores the curve's position to its prior path.

Catch-up growth ${ }^{2-6}$ and the investigation of its underlying mechanisms $\mathrm{s}^{7,8}$ are discussed in the available bibliography, but there is undoubtedly a regulatory force that tends to maintain growth (and development) within a specific channel.

In this article, I focus on what occurs in the previous stage: growth (and development) retardation in relation to sex differences, i.e., the different response boys and girls have when faced with the same injury. Figure 2 shows the growth curve of a boy and his sister; both suffered at the same time an episode of prolonged diarrhea of unknown etiology, which resolved only after a long time.

The boy's growth curve deviated much more markedly than the girl's curve. In the same situation, the girl 
FIGURE 1. Growth curve for height of a girl with hypothyroidism due to lingual thyroid, before and after treatment

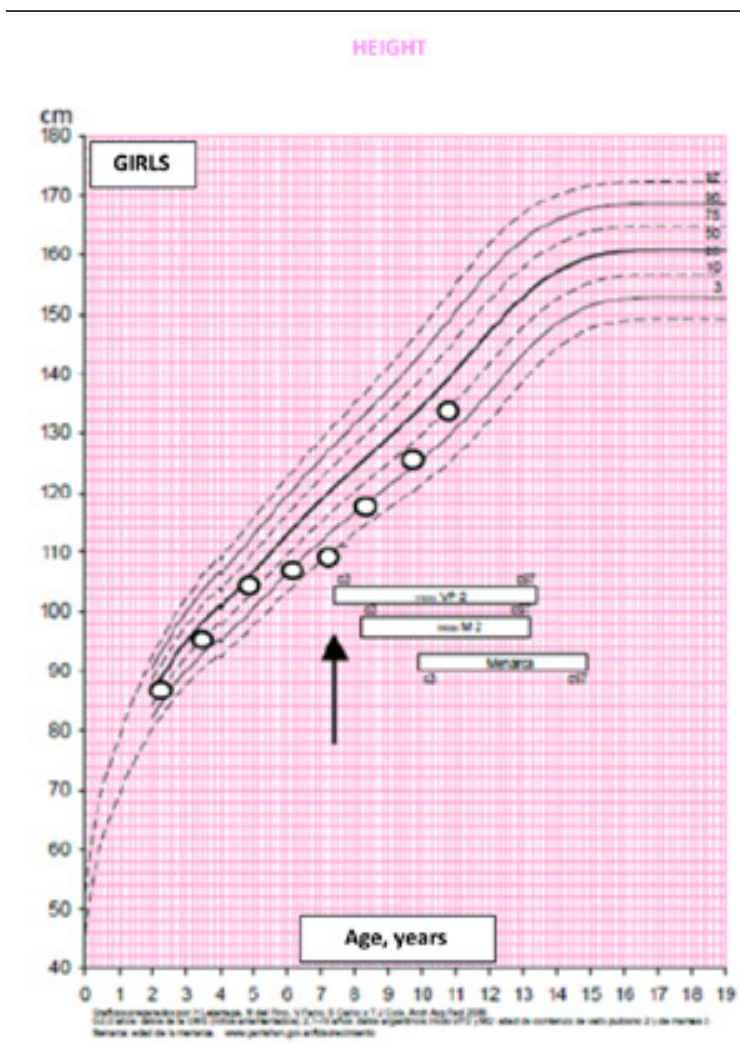

Source: Personal observation. had a better curve canalization than the boy. A more severe damage is required to deviate the growth curves of girls compared to boys.

This is a clinical example, but the phenomenon is also observed in epidemiological research. ${ }^{9}$ The results of 16 anthropometric studies conducted in Sub-Saharan Africa reflected a higher prevalence of short stature among boys compared to girls. ${ }^{10}$ The difference in favor of girls remains constant in all studied countries. This is only an example of what has been observed in all anthropometric surveys reviewed. Although this is a universal phenomenon, regardless of the region, there are some exceptions. If predominance among girls is not observed, or the contrary is noted, it is necessary to look for a reason, which may be that some societies prioritize, as a social value, the upbringing of boys over girls. ${ }^{11}$ Sometimes, such reversal in sex differences does not have a clear explanation. ${ }^{12}$ Anyhow, it may be said that the higher prevalence of boys with growth retardation due to generalized damage is universal. Male adolescents exposed to prenatal radiation as a result of the Hiroshima and Nagasaki A-bombings showed a greater growth retardation than female adolescents. ${ }^{13}$

More recent studies published abroad showed similar results, ${ }^{14}$ but certainly the most important anthropometric study in Argentina's auxological

FIGURE 2. Growth curves of two siblings with chronic diarrhea
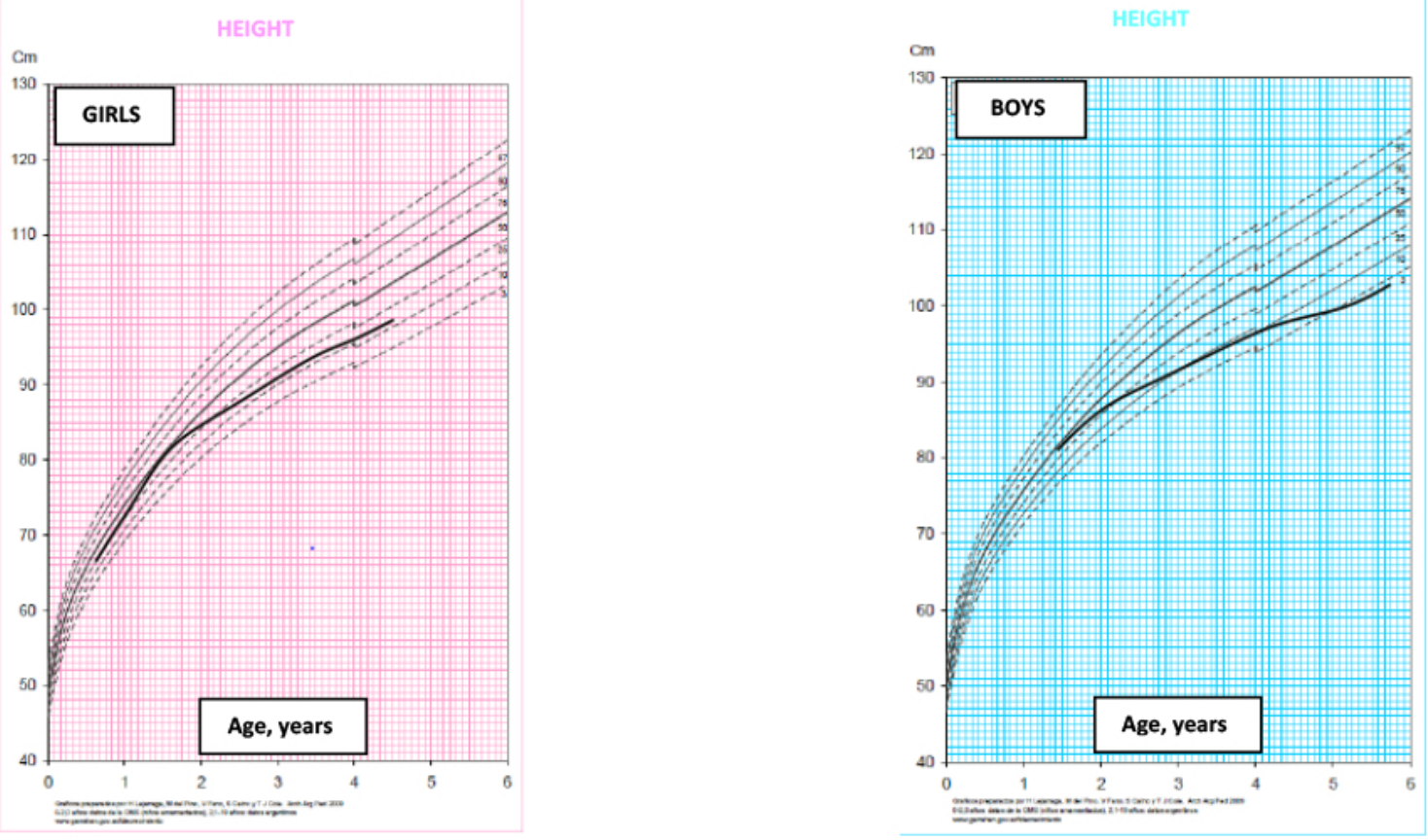

Source: Personal observation. 
history (and probably one of the biggest samples used worldwide) has been conducted by Nuñez et al. in 2016. ${ }^{15}$ In the 2004-2015 period, Argentina implemented 2 health care and coverage plans: Plan Nacer and Plan Sumar (from 2005 to 2013), which protected, among others, children younger than 6 years. Weight and height were measured in 1.5 million children aged 0-5 years. Approximately 13 million anthropometric data were analyzed. In addition to a $46 \%$ reduction in the rate of children with short stature and low weight observed over the studied period, a higher prevalence of short stature and low weight was noted among boys in all study years. Table 1 shows such differences.

Over the years during which the plans were implemented, the prevalence of short stature decreased progressively over the years, but the difference in prevalence in favor of girls remained constant.

\section{CANALIZATION OF DEVELOPMENT}

Canalization is also observed in psychomotor development, although for some reason, it has not sparked as much interest in the bibliography. In this field, it is also possible to imagine a channel along which children mature, at a faster or slower tempo. ${ }^{16}$

FIGURE 3. Example of re-canalization of psychomotor development

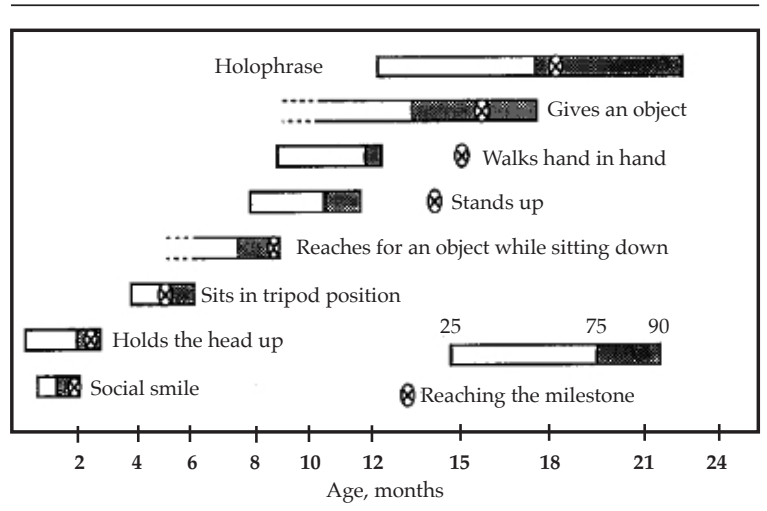

Source: Lejarraga, $2004 .{ }^{16}$
Figure 3 shows the age at the time of achievement of milestones in a child whose family experienced a traumatic move and city relocation, with severe consequences on the family harmony (maternal depression and panic attack) and on the child's development. ${ }^{17}$

The Xs indicate the child's age at the time of passing the milestone, whereas the rectangles show the age range at which milestones are normally achieved, according to the national reference. ${ }^{18}$ The right end of the rectangle accounts for the $90^{\text {th }}$ percentile of the age at attainment of the milestone; the left end of the shaded area, the $75^{\text {th }}$ percentile, and the left end of the rectangle, the $25^{\text {th }}$ percentile.

Up to 7 months old, the child achieved maturation milestones at the usual age: social smile at 2 months old, held his head at 3 months old, and sat at 6 months old. But at 7 months old, his father lost his job, a family crisis erupted, his mother became ill, and the whole family ( 2 other children) was forced to move and relocate in another city. As of that time, the child's development literally stopped. Such interruption lasted several months, until at 16 months old, his father got a new job; his mother's health recovered; and the family's situation improved substantially, especially that of his mother. The child's development accelerated and he rapidly started attaining delayed milestones. Such tempo acceleration (maturation speed) is also an example of canalization.

Another assessment of the prevalence of developmental disorders is the study of the proportion of children in a community who fail the National Screening Test (Prueba Nacional de Pesquisa, PRUNAPE). The PRUNAPE is aimed at detecting unapparent developmental problems in children younger than 6 years, ${ }^{19}$ and has been used in several Argentine studies. In one of these studies, the PRUNAPE was administered to a sample of communities living in unfavorable settings (a high rate of families with unmet basic needs [UBNs]) from 14 municipalities in the Matanza-Riachuelo River Basin by the General Environmental Health Division of the Matanza-

TABle 1. Prevalence (\%) of children with short stature, by sex

\begin{tabular}{llllllllll}
\hline Year & $\mathbf{2 0 0 5}$ & $\mathbf{2 0 0 6}$ & $\mathbf{2 0 0 7}$ & $\mathbf{2 0 0 8}$ & $\mathbf{2 0 0 9}$ & $\mathbf{2 0 1 0}$ & $\mathbf{2 0 1 1}$ & $\mathbf{2 0 1 2}$ & $\mathbf{2 0 1 3}$ \\
\hline Boys & 22.0 & 20.4 & 18.9 & 17.6 & 16.4 & 15.3 & 14.3 & 13.4 & 12.7 \\
Girls & 19.2 & 17.6 & 16.2 & 14.8 & 13.0 & 12.5 & 11.5 & 10.7 & 9.9 \\
\hline
\end{tabular}

Source: Nuñez et al., 2016. ${ }^{14}$ 
Riachuelo River Basin Authority (Autoridad de Cuenca Matanza Riachuelo, ACUMAR). ${ }^{20}$

A considerable difference was observed in the prevalence of children who failed the PRUNAPE. In unfavorable settings, girls are less affected than boys and manage to better maintain their channel of development.

Another survey also administered by the General Environmental Health Division of ACUMAR in 2014 in populations with a high rate of families with UBNs from La Matanza and Florencio Varela found a higher prevalence of boys who failed the PRUNAPE compared to girls (39.7\% versus $29.7 \%$, respectively). This is also a generalized finding. ${ }^{21,22}$

The higher vulnerability of boys is also noted in the higher prevalence of many developmental disorders (language, attention disorders, autism, cerebral palsy). ${ }^{23-27}$ Such differences are not observed in some disorders, as is the case of cognitive disorders, infant depression, ${ }^{28,29}$ and academic performance. ${ }^{30}$ And when differences are noted, they are not systematic or prevalent in a specific sex. Some investigators studied whether girls with higher scores in motor skills than boys had been affected by their parents' attitudes. That study evidenced that parental attitudes may have certain effect by stimulating differences, but they cannot be explained exclusively by them. ${ }^{31}$

The fact that those findings were encountered across all communities and all age groups strongly suggests that the cause of such better canalization in favor of girls has a genetic nature. Genetic differences in physiological mechanisms already

TABLE 2. Proportion of children who fail the PRUNAPE

\begin{tabular}{lccc}
\hline Sex & Total (N) & Fail the PRUNAPE (N) & $\mathbf{( \% )}$ \\
\hline Boys & 701 & 273 & 38.9 \\
Girls & 640 & 182 & 28.4 \\
\hline
\end{tabular}

PRUNAPE: National Screening Test.

Source: ENUDPAT I Survey. DGSA, ACUMAR, 2012. ${ }^{19}$ present at birth have even been suggested..$^{32}$ It is not known whether such genetic regulation may be modulated by epigenetic factors.

Some examples also indicate that such canalization is expressed in diseases not related to development. Many diseases are more common (and more severe) among males, e.g., asthma, but such sex preference is only observed during childhood because the male/female ratio during adulthood may be reversed, with asthma being more frequent among females. It has been argued that such change in the male/female ratio is because asthma develops later in girls. ${ }^{33}$ In turn, some other diseases are more common and more severe among females, so it is not possible to extend the concept of canalization to all pediatric diseases.

However, sex differences in favor of girls are not limited to the canalization of growth and development and the incidence of some diseases, but to other equally important health-related aspects, such as mortality and life expectancy. Overall mortality is always higher among men than women, ${ }^{34}$ but, although environmental factors have been insinuated as the cause, it has been observed that a higher male mortality is also present in children and even in infants. Table 3 shows infant mortality data in Argentina between 2014 and 2019. ${ }^{34}$

The differences in mortality across all studied years remain constant between $16 \%$ and $20 \%$ in favor of girls. In addition to such values, we should also consider that each year more boys than girls are born, approximately 106 boys per every 100 girls. This means that the sex ratio ( $\mathrm{SR}=$ no. of males $/$ no. of females) is approximately 1.06 at birth, ${ }^{35}$ and since male mortality is higher than female mortality at all ages, the SR decreases with age and reaches 1.0 at approximately 20 years old and then continues to decline steadily.

Even in the setting of the current novel coronavirus disease 2019 (COVID-19) pandemic, the disease has a bigger toll on males than

TABLE 3. Infant mortality in Argentina, by sex

\begin{tabular}{lcccccc}
\hline & $\mathbf{2 0 1 4}$ & $\mathbf{2 0 1 5}$ & $\mathbf{2 0 1 6}$ & $\mathbf{2 0 1 7}$ & $\mathbf{2 0 1 8}$ & $\mathbf{2 0 1 9}$ \\
\hline Younger than 1 year old & 11.1 & 10.8 & 10.6 & 9.7 & 9.7 & 9.3 \\
Boys & 11.9 & 11.8 & 11.5 & 10.6 & 10.7 & 10.2 \\
Girls & 10.1 & 9.8 & 9.5 & 8.6 & 8.7 & 8.6 \\
\hline
\end{tabular}

Source: National Statistics and Censuses Institute of Argentina (Instituto Nacional de Estadísticas y Censos, INDEC). Indicadores de salud. Diciembre. Ministerio de Salud. Estadísticas vitales. Información básica. Argentina 2018. N. ${ }^{\circ} 62$. Ministerio de Salud de la Nación. Argentina. 2019. ${ }^{34}$ 
females. Table 4 shows mortality by sex from the 421370 COVID-19 deaths reported by the National Center for Health Statistics (NCHS) to the United States Centers for Disease Control and Prevention (CDC) up to January $30^{\text {th }}, 2021 . .^{36}$

In the United States, the prevalence of male deaths is very clear, with a ratio of 1.19. The same sex prevalence has been reported in China. ${ }^{37}$

Lastly, to make such statements even more convincing, Table 5 shows the life expectancy of different countries, by sex and in different years.

Aside from the fact that Argentina needs to improve life expectancy by far in relation to other countries, the difference in favor of women (which is not new information for many of our readers) is observed in all countries and remains constant over all the studied years. This is a universal fact, without exception. On average, women live longer than men.

Therefore, the concept of canalization (although disseminated by researchers devoted to growth and development) extends beyond these fields of study and expresses a greater lability among males in terms of certain nutritional deficits, diseases, mortality, and even a shorter life expectancy.

\section{CONCLUSION}

The concept of canalization was introduced by Waddington in the setting of developmental biology. ${ }^{38}$ He defined 2 major concepts: one is that, from the original egg or zygote, each cell group is differentiated into diverse tissues, each trending towards a great specialization in relation to the other tissues. The other concept considers that, if in the course of such differentiation (due to either an internal or external process), any factor deviates it from its path, such deviation is rapidly corrected by regulatory processes which have not yet been identified. This takes place not only in tissue development but across the whole individual, in the size and shape of organs and the body as a whole. The mechanisms of such

TABLE 4. COVID-19 death counts reported by the NCHS between January $1^{\text {st }}, 2020$ and January $30^{\text {th }}, 2021$

\begin{tabular}{ll}
\hline Total deaths & 421370 \\
Females & 192545 \\
Males & 228825 \\
\hline
\end{tabular}

Source: United States Centers for Disease Control and Prevention (CDC). ${ }^{37}$ regulation are unknown, but there is one certain thing: it is stronger in girls than boys.

This is true in human beings and other mammals. ${ }^{39}$ Girls show a smaller deviation from their biological channel than boys and, in turn, they catch up faster than boys. The reasons for such differences are unknown, but based on all the evidence described, it may be stated (together with other authors) that they are certainly subjected to a strong genetic influence. ${ }^{40,41}$

The objective of this article does not include describing the theories regarding canalization, but, undoubtedly, there are strong, underlying regulatory mechanisms. Such mechanisms have not been individually elucidated yet and may be based on molecular, cellular, hormonal or metabolic factors, although there is still not enough evidence on this topic. Anyone who wishes to offer an understanding and explanation of genetic canalization and related sex differences from a mechanistic perspective will need to develop conceptual and methodological estimations that should integrate quantitative genetics and developmental biology and even consider epigenetic and empirical influences. ${ }^{42}$

Sex differences in canalization have a strong biological significance ${ }^{43}$ and should always be present for anyone studying the epidemiological aspects of child health.

\section{Acknowledgments}

I would like to thank Gabriela Obregón, M.D., for her feedback on the text; Alicia Masautis, B.S., and Celina Lejarraga, M.D., for reviewing the manuscript.

\section{REFERENCES}

1. Prader A, Tanner JM, von Harnack G. Catch up growth after disease or starvation. An example of developmental canalization in man. J Pediatr. 1963; 62:646-59.

TABLE 5. Life expectancy (years), by sex, 2018

\begin{tabular}{lcc}
\hline Country & Females & Males \\
\hline Germany & 83.3 & 78.6 \\
Argentina & 79.9 & 73.1 \\
Bolivia & 74.2 & 68.4 \\
Brazil & 79.4 & 72 \\
Canada & 84.1 & 79.9 \\
Chile & 82.4 & 77.5 \\
Spain & 86.3 & 80.7 \\
United Kingdom & 83.1 & 79.5 \\
\hline
\end{tabular}

Source: https: / / datosmacro.expansion.com/demografia / esperanza-vidapmental tempo 2020 https: / / www.indec. gob.ar/indec/web/Nivel4-Tema-4-32-94. 
2. TannerJM. Fetusintoman. Physical growth from conception to maturity. $2^{\text {nd }}$ ed. London: Open Books; 1978.

3. Tanner JM. Catch-up growth in man. Br Med Bull. 1981; 37(3):233-8.

4. Boersma M, Wit JM. Catch up growth. Endocr Rev. 1997; 18(5):646-61.

5. De Wit CC, Sas TCJ, Wit JM, Cutfield WS. Patterns of catch up growth. J Pediatr. 2013; 162(2):415-20.

6. Tanner JM. Growth as a target-seeking function; catch-up and catch-down growth in man. In Falkner F, Tanner JM (eds). Human Growth. Boston:Springer; 1986.Pages.167-79.

7. Ko JM, Park HK, Yang S, Hwang I. Influence of catch-up growth on IGFBP-2 levels and association between IGFBP-2 and cardiovascular risk factors in Korean children born SGA. Endocr J. 2012; 59(8):725-33.

8. Gafni RI, Baron J. Catch-up growth: possible mechanisms. Pediatr Nephrol. 2000; 14(7):616-9.

9. DakeSK, Solomon FB, Bobe TM, Tekle HA, et al. Predictors of stunting among children 6-59 months of age in Sodo Zuria District, South Ethiopia: a community based crosssectional study. BMC Nutr. 2019; 5:23.

10. Wamani H, Astrom AN, Peterson S, Tmwine JK, et al. Boys are more stunted than girls in Sub-Saharan Africa: a meta-analysis of 16 demographic and health surveys. BMC Pediatr. 2007; 7:17 AM.

11. Himaz R. Stunting later in childhood and outcomes as a young adult: evidence from India. World Dev. 2018; 104:34457.

12. Kain J, Uauy R, Vio F, Albala C. Trends in overweight and obesity prevalence in Chilean children: comparison of three definitions. Eur J Clin Nutr. 2002; 56(3):200-4.

13. Shohoji T, Pasternack B. Adolescent growth patterns in survivors exposed prenatally to the A Bomb in Hiroshima and Nagasaki. Health Phys. 1973; 25(1):17-27.

14. Decaro JA, Decaro E, Worthman CM. Sex differences in child nutritional and immunological status 5-9 years post contact in fringe highland Papua New Guinea. Am J Hum Biol. 2010; 22(5):657-66.

15. NuñezPA, Fernández-SlezakD, Farall A, Szretter ME, etal. Impact of Universal Health Coverage on Child Growth and Nutrition in Argentina. Am J Public Health. 2016; 106(4):7206.

16. LejarragaH,Kelmansky D, NunesF. Tempodedesarrollode niños de 0 a 5 años que viven bajo circunstancias ambientales desfavorables. Arch Argent Pediatr. 2018; 116(2):e210-5.

17. Lejarraga H. La interacción entre genética y medioambiente. In: Lejarraga H. Desarrollo del niño en contexto. Buenos Aires: Paidós; 2004.Page.107.

18. Lejarraga H, Krupitzky S, Kelmansky D, Martínez E, et al. Edad de cumplimiento de pautas de desarrollo en niños argentinos sanos menores de seis años. Arch Argent Pediatr. 1996; 94(6):355-67.

19. LejarragaH,Kelmansky D, PascucciC, Salamanco G. Prueba Nacional de Pesquisa, Manual Técnico 2013. Buenos Aires: Fundación Hospital de Pediatría Garrahan; 2013.

20. Lejarraga H, Pascucci MC, Masautis A, Kelmansky D, et al. Desarrollo psicomotor infantil en la Cuenca MatanzaRiachuelo: Pesquisa de problemas inaparentes del desarrollo. Rev Argent Salud Pública. 2014; 19(5):17-24.

21. Drachler ML, Marshall TA, de Carvalho Leite JC. A continuous $\square$ scale measure of child development for population $\square$ based epidemiological surveys: a preliminary study using Item Response Theory for the Denver Test. Paediatr Perinat Epidemiol. 2007; 21(2):138-53.

22. Lejarraga H, Menéndez A, Menzano E, Guerra L, et al. Screening for developmental problems at primary care level: a field programme in San Isidro, Argentina. Paediatr Perinat Epidemiol. 2008; 22(2):180-7.
23. Werling DM, Geschwind DH. Sex differences in autism spectrum disorders. Curr Opin Neurol. 2013; 26(2):146-53.

24. Szatmari P, Offord DR, Boyle MH. Ontario Child Health Study: prevalence of attention deficit disorder with hyperactivity. J Child Psychol Psychiatry. 1989;30(2):219-30.

25. Barbaresi WJ, Katusic SK, Colligan RC, Pankratz VS, et al. How common is attention-deficit/ hyperactivity disorder? Incidence in a population-based birth cohort in Rochester, Minn. Arch Pediatr Adolesc Med. 2002; 156(3):217-24.

26. Viding E, Spinath FM, Price TS, Bishop D, et al. Genetic and environmental influence on language impairment in 4-year-old same-sex and opposite-sex twins. JChild Psychol Psychiatry. 2004; 45(2):315-25.

27. Chounti A, Hägglund G, Wagner P, Westbom L. Sex differences in cerebral palsy incidence and functional ability: a total population study. Acta Paediatr. 2013; 102(7):712-7.

28. Piccinelli M, Wilkinson G. Gender differences in depression. Br J Psychiatry. 2000; 144(6):486-92.

29. Ardila A, Rosselli M, Matute E, Inozemtseva O. Gender differences in cognitive development. Dev Psychol. 2011; 47(4):984-90.

30. Matthews JS, Ponitz CC, Morrison FJ. Early gender differences in self-regulation and academic achievement. J Educ Psychol. 2009; 101(3):689-704.

31. DinkelD, Snyder K. Exploring gender differences in infant motor development related to parent's promotion of play. Infant Behav Dev. 2020; 59:101440.

32. Nagy E, Loveland KA, Orvos H, Molnár P. Gender-related physiologic differences in human neonates and greater vulnerability of males to developmental brain disorders. J Gend Specif Med. 2001; 4(1):41-9.

33. Nicolai T, Pereszlenyiova L, Sabmina L, Reinhardt D, Von Mutius E. Longitudinal follow $\square$ up of the changing gender ratio in asthma from childhood to adulthood: role of delayed manifestation in girls. Pediatr Allergy Immunol. 2003; 14(4)280-3.

34. Argentina. Ministerio de Salud. Indicadores de salud. Estadísticas vitales. Información básica: Argentina 2018. 2019;5(62). [Accessed on: April 20 ${ }^{\text {th }}, 2021$ ]. Available at: http: / / www.deis.msal.gov.ar/wp-content/ uploads / 2020/01/Serie5Nro62.pdf

35. Dirección General de Estadísticas y Censos. Ministerio de hacienda y finanzas. Índice de masculinidad por grupos de edad según Circunscripción electoral. Ciudad de Buenos Aires. Años 1991-2001. Gobierno de la ciudad de Buenos Aires. [Accessed on: April 20 ${ }^{\text {th }}$, 2021]. Available at: https: / / www.estadisticaciudad.gob.ar/eyc/? $\mathrm{p}=28074$

36. CDC. Centers for Disease Control and Preventions. Provisional Covid-19 death counts by sex, age and state. [Accessed on: March 4 $\left.{ }^{\text {th }}, 2021\right]$. Available at: https: / / data. cdc.gov/NCHS / Provisional-COVID-19-Death-Counts-bySex-Age-and-S/9bhg-hcku

37. Jang JK. Diferencias en la gravedad y la mortalidad por Covid-19 en relación con el sexo. Front Public Health. SIIC Salud. Textos completos autorizados [Accessed on: February $4^{\text {th }}$, 2021]. Available at: https: / / www.siicsalud.com/ dato/ resiiccompleto.php/163538

38. Waddington $\mathrm{CH}$. Canalization of development and the inheritance of acquired characters. Nature.1942; 150:563-5.

39. Hallgrímsson B, Willmore K, Hall BK. Canalization, developmental stability, and morphological integration in primate limbs. Am J Phys Anthropol. 2002; (Suppl 35):13158.

40. Hallgrimsson B, Green RM, Katz DC, Fish JL, et al. The developmental genetics of canalization. Semin Cell Dev Biol. 2019; 88:67-79.

41. Sharloo W. Canalization: genetic and developmental 
aspects. Annu Rev Ecol Syst. 1991; 22:65-93.

42. Blair C, Raver CC. Child Development in the Context of Adversity: experiential canalization of brain and behavior.
Am Psychol. 2012; 67(4):309-18.

43. Debat V, Le Rouzic A. Canalization, a central concept in biology. Semin Cell Dev Biol. 2019; 88:1-3. 